\title{
Utilization of a seagrass meadow and tidal marsh creek by blue crabs Callinectes sapidus. I. Seasonal and annual variations in abundance with emphasis on post-settlement juveniles*
}

\author{
Robert J. Orth, Jacques van Montfrans \\ Virginia Institute of Marine Science, School of Marine Science, College of William and Mary, Gloucester Point, Virginia 23062, \\ USA
}

\begin{abstract}
Blue crabs Callinectes sapidus Rathbun were sampled in a lower Chesapeake Bay seagrass bed and adjacent tidal marsh creek from October 1982 through December 1986, using a drop net and suction sampler. Suction sampling was $88 \%$ efficient and provided more accurate estimates of juvenile blue crab abundance, that were at least an order of magnitude greater than those obtained by conventional trawl gear For data analysis, C. sapidus were separated into 4 size classes by carapace width: $\leq 4.25 \mathrm{~mm}$ (recently settled $1 \mathrm{st}$ and 2 nd juveniles); 4.25 to $11.00 \mathrm{~mm}$ (3rd through 7 th juvenile crabs); $>11.00$ to $\leq 25.00 \mathrm{~mm}$ (8th through 12 th juvenile crabs); and $>25.00 \mathrm{~mm}$ (older juveniles and adults). Seasonal and annual cycles of $C$. sapidus abundance were observed in both habitats with annual differences most pronounced in the grassbed. Densities of $C$. sapidus were significantly greater in the grassbed in all but 2 of the 48 sampling dates. Settlement of the new year class appeared to be by megalopae and occurred from August through December A pulse of small C. sapidus $<4.25 \mathrm{~mm}$ was observed in the grassbed from early to mid-September, whereas in the marsh creek this pulse occurred 2 to $4 \mathrm{wk}$ later and consisted of $3 \mathrm{rd}$ stage and generally larger crabs $(>4.25 \mathrm{~mm}$ ). The small numbers of 1 st and 2nd stage juvenile crabs $(<4.25 \mathrm{~mm})$ in the marsh creek in contrast to their abundance in the grassbed may result from increased predation in the tidal marsh creek or selective settlement into the grassbed. C. sapidus were rare in the marsh creek in winter but densities of crabs $\leq 25 \mathrm{~mm}$ remained high in the grassbed from fall through early spring. Densities decreased gradually in both habitats to lowest levels by mid-August. Approximately $90 \%$ or more of C. sapidus collected at both sites from late August to June were $\leq 25 \mathrm{~mm}$ in carapace width. Densities of individuals 11 to $25 \mathrm{~mm}$ and $>25 \mathrm{~mm}$ throughout the study period did not differ significantly among years (1983 to 1986) even though there were significant differences in the abundance of smaller sized individuals between 1983-84 and 1985-86. This suggests mortality within or emigration from grassbeds around this size. A possible ontogenetic shift in habitat use by crabs 11 to $25 \mathrm{~mm}$ may reflect a refuge in size from predation.
\end{abstract}

\section{INTRODUCTION}

A critical stage for many benthic marine invertebrates occurs when larvae transform from a planktonic to a benthic phase. For many species little is known about variations in settlement over space and time, the biotic and abiotic factors which affect the density and distribution of settlers, and the relationships between settlement density and post-settlement survival (Connell 1985). Based on the few cases where this transition

\footnotetext{
- Contribution No. 1412 of the Virginia Institute of Marine Science
}

has been closely observed (Keough \& Downes 1982 , Connell 1985, Wethey 1985) both variation and mortality appear to be high in the settling stage. A more complete understanding of the variations associated with recruitment for most species is required before we can begin to ascribe causal relationships to pre- or postsettlement processes (Connell 1985).

In western Atlantic estuaries such as Delaware Bay and Chesapeake Bay, the blue crab Callinectes sapidus Rathbun has a life cycle that entails migration by adult females to the estuary mouth for subsequent release of zoeae. Early zoeae remain near the surface and are advected from the estuary to develop in high salinity 
waters of the continental shelf (Sandifer 1975. Sulkin et al. 1980, Dittel \& Epifanio 1982, Epifanio \& Dittel 1982 Sulkin \& van Heukelem 1982, Sulkin et al. 1982, McConaugha et al. 1983, Provenzano et al. 1983 , Epifanio et al. 1984, Sulkin 1984, van den Avyle \& Fowler 1984). The mechanism of $C$. sapidus recruitment back into the estuary and associated tributaries is presently being debated, but apparently entails southeasterly wind patterns near the mouth for larval retention (D. R. Johnson et al. 1984, D. R. Johnson 1985) coupled with late zoeal and megalopal behavioral responses to light, gravity and pressure (Sulkin et al 1982, Sulkin 1984, Brookins \& Epifanio 1985, D. F. Johnson 1982, 1985).

Once megalopae enter the estuary and become associated with the benthos little is known about their utilization of different habitats (Weinstein \& Brooks 1983, Hines et al. 1987). In Chesapeake Bay, higher abundances of large Callinectes sapidus were collected with otter trawls in areas with submerged aquatic vegetation than in unvegetated areas (Heck \& Orth 1980 Weinstein \& Brooks 1983, Heck \& Thoman 1984). Heck \& Thoman (1984) concluded that beds of submerged aquatic vegetation in high salinity areas of Chesapeake Bay (i.e. the Virginia portion) were more important nursery areas for $C$ sapidus than similar low salinity
$(<10 \%$ ) areas (i.e. the Maryland portion). Penry (1982) found much higher densities of small crabs $(<25 \mathrm{~mm})$ in vegetated areas than had the previous authors. Though it appears that vegetated habitats may be important for very young $C$. sapidus, little is known about the temporal (from diel to annual) patterns of settlement and recruitment into different habitats. In this paper, we report on the seasonal and annual abundance patterns of $C$. sapidus inhabiting a seagrass bed and adjacent tidal marsh creek over a 49 mo period with an emphasis on juveniles $<25 \mathrm{~mm}$ in carapace width.

\section{STUDY SITE}

The sampling site was located in Mobjack Bay, Virginia, USA, near the mouth of the York River $\left(37^{\circ} 17.45^{\prime} \mathrm{N}, 76^{\circ} 22.65^{\prime} \mathrm{W}\right)$ in the Guinea Marshes (Fig. 1). This area contains an extensive system of Spartina alterniflora dominated marsh creeks including Little Monday Creek which terminates in a broad subtidal sand flat. A portion of this flat is vegetated by approximately 98 ha of eelgrass Zostera marina and widgeongrass Ruppia maritima. Sampling was conducted in the grassbed and a small tidal marsh creek tributary of Little Monday Creek

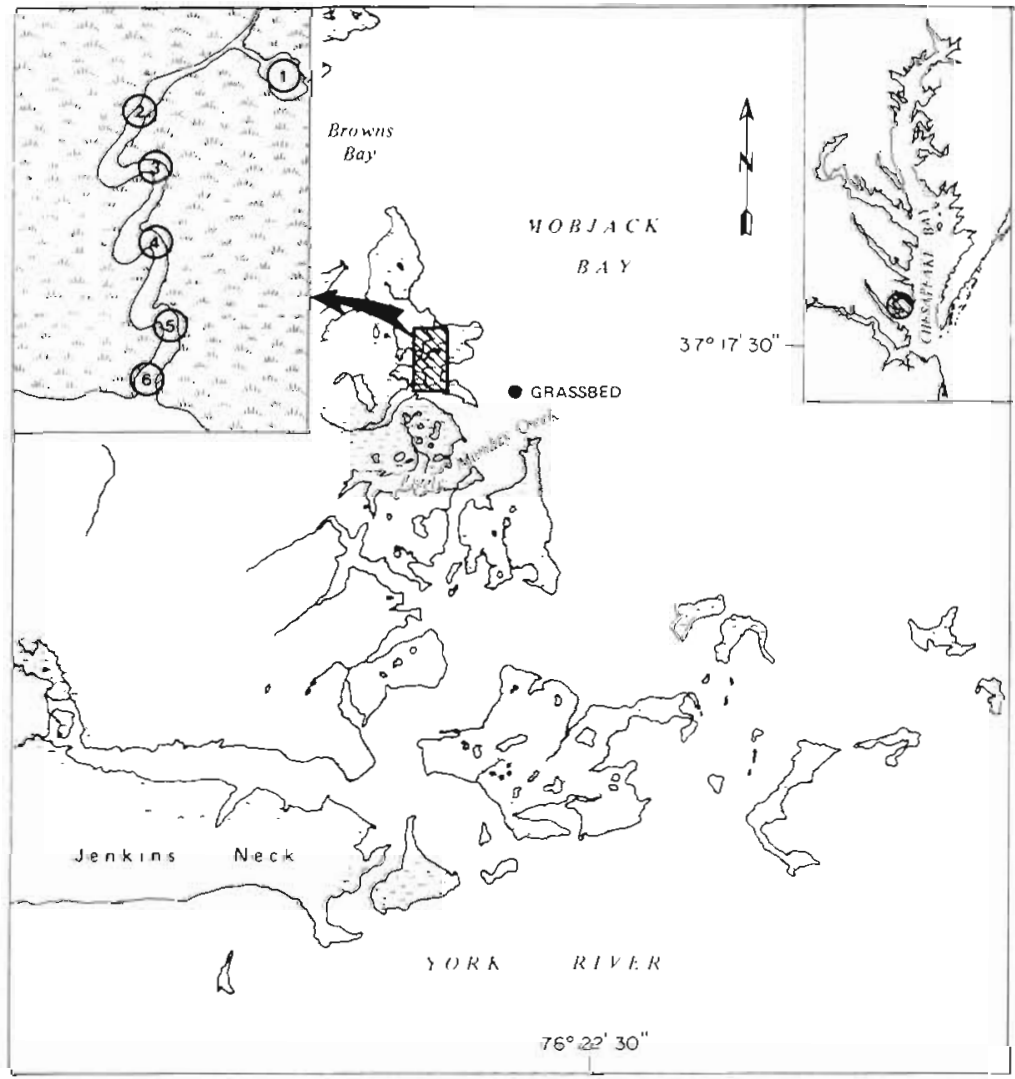

Fig. 1. Location of sampling sites in the grassbed and tidal marsh creek in the lower Chesapeake Bay. Numbers in the creek indicate sampling stations 


\section{MATERIALS AND METHODS}

Callinectes sapidus were sampled using 6 cylindrical $3 \mathrm{~m}^{2}$ drop nets and a suction sampler (Fig. 2). Drop nets were randomly deployed from a boat at the grassbed site over 6 areas with $100 \%$ vegetation cover, and from the marsh bank over 6 stations at various distances from the creek mouth (Fig. 1). All samples were collected around high tide in the marsh creek and $\pm 3 \mathrm{~h}$ of high tide in the grassbed. Water depths at high slack water ranged from 1 to $1.5 \mathrm{~m}$ in the marsh creek and 1.5 to $1.75 \mathrm{~m}$ in the grassbed. Mean tide range was approximately $0.8 \mathrm{~m}$.

After deployment of all 6 drop nets, the bottom enclosed by each net was suctioned for $10 \mathrm{~min}$ and subsequently dip-netted with a fine mesh $(1.2 \mathrm{~mm})$ net for an additional $5 \mathrm{~min}$. Surface sediment and debris were removed by the suction sampler to depths of 2 to $3 \mathrm{~cm}$ in the grassbed (leaving most of the grass intact) and 3 to $5 \mathrm{~cm}$ in the marsh creek. All Callinectes sapidus survived sampling except for soft crabs which could be counted but not accurately measured.

Samples were immediately returned to the laboratory and live-sorted for Callinectes sapidus which were then preserved in $10 \%$ formalin and later measured for carapace width (distance across the posterior lateral spines). All subsequently reported crab sizes refer to this measurement. Crabs $<15 \mathrm{~mm}$ were measured to the nearest $0.01 \mathrm{~mm}$ with an ocular micrometer in a Wild M-5 dissecting microscope. Those > $15 \mathrm{~mm}$ were measured with calipers. Additionally, depending on overall densities, as many as 50 or more crabs per collection from each habitat were sexed.

Samples were collected from 18 Oct 1982 to 10 Dec 1986. Sampling in 1982 and 1983 was conducted semimonthly (spring and fall) or monthly to determine major periods of settlement/recruitment (sensu Connell 1985), resulting in 21 sampling periods. Sampling in 1984, 1985 and 1986 was less intensive than in 1982-1983 and was designed to examine the major period of Callinectes sapidus settlement/recruitment (fall). Thus, samples were collected every $2 \mathrm{wk}$ in August and September ( 5 dates) with additional collections made in winter, spring and summer (4 dates), resulting in 9 sampling periods in each of 1984, 1985 and 1986 .

For the purpose of analysis, crabs were separated into 4 groups to reflect various juvenile size classes (Millikin \& Williams 1984, and our size frequency data): $<4.25 \mathrm{~mm}$ representing the first 2 juvenile stages; 4.25 to $11.00 \mathrm{~mm}$ for juvenile stages 3 through $7 ;>11.00$ to $25.00 \mathrm{~mm}$ for juvenile stages 8 through 12 ; and $>25.00 \mathrm{~mm}$ for stages 13 and above. These size groupings were selected to emphasize the recently settled $(<4.25 \mathrm{~mm})$ or recruited $(4.25$ to $11.00 \mathrm{~mm})$ segment of the population.

All data (1982 to 1986) were cross-classified by habitat, crab size, sex, and month of collection to examine differences in sex ratios using log-linear models (Fienberg 1980). Additionally, patterns of crab

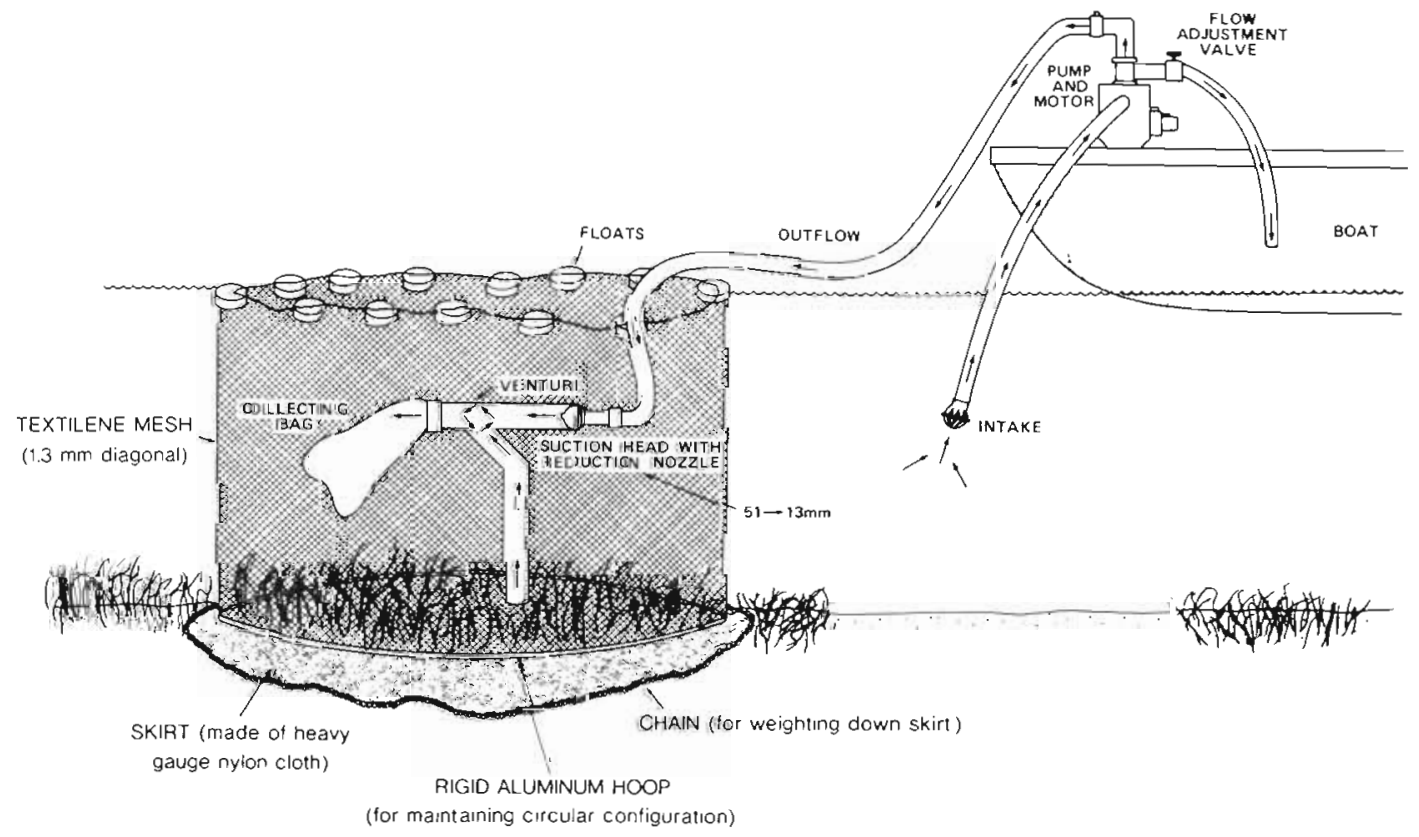

Fig. 2. Schematic diagram of suction sampler and sampling frame used in crab sampling. The cylindrical frame enclosed $3 \mathrm{~m}^{2}$ of bottom. Distance from the floats to aluminum hoop was $1.4 \mathrm{~m}$ (but was adjustable depending on the tide by using draw strings to keep the sides vertical) and from the hoop to the chain was $14 \mathrm{~cm}$ 
abundance on each date were compared for both habitats using a Mann-Whitney U-test (Sokal \& Rohlf 1981) since sample variances were heteroscedastic.

Annual patterns of settlement and post-settlement density were best reflected in data from the grassbed. These data were grouped across years to reflect Callinectes sapidus abundance during spring (samples collected between $26 \mathrm{Mar}$ and $2 \mathrm{Apr}$ ), summer (8 to 31 Jul), the fall settlement period (5 to 15 Aug; 29 Aug to $2 \mathrm{Sep} ; 10$ to $16 \mathrm{Sep} ; 24$ to $30 \mathrm{Sep}$ ) and early winter (12 Nov to $10 \mathrm{Dec}$ ). Contingency table analysis (Fienberg 1980) was then used to examine effects of season and year on density of crabs within the 4 size groups discussed above. Additionally, total density in each size category was compared across years using a KruskalWallis 1-way ANOVA (Sokal \& Rohlf 1981) since sample variances were heteroscedastic. The effects of all statistical tests were considered significant at the 0.05 level of $\alpha$.

Temperature and salinity were recorded in both habitats during sampling periods. Continuous water temperature data were also available from a sensor located $10 \mathrm{~km}$ upriver from our sampling site for comparison with our point sampling. Above-ground standing crop of the submerged vegetation was measured quarterly from 5 random $0.033 \mathrm{~m}^{2}$ cores taken adjacent to drop net samples.

Several aspects of sampling methodology were addressed in this study. Suction sampling efficiency was determined by deploying 6 drop nets in each habitat and introducing 10 Callinectes sapidus marked with indelible ink into each net. Only uninjured, active hard crabs ranging in size from 22 to $102 \mathrm{~mm}$ in carapace width (mean carapace width: $51 \mathrm{~mm}$ ) were marked after being collected in adjacent areas by otter trawling. Suction sampling commenced at least $1 \mathrm{~h}$ after introducing crabs into the nets. Sampling efficiency in the grassbed $(88 \%)$ did not differ significantly ( $A N O V A_{i} p=0.82$ ) from that in the marsh creek $(85 \%)$. It was assumed that sampling efficiency for smaller, less mobile C. sapidus would be at least as great as that for the larger crabs used in the gear efficiency test.

Crab density estimates in the grassbed obtained by suction sampling were compared to those obtained by otter trawling $(4.9 \mathrm{~m}$ wide trawl with a $0.6 \mathrm{~mm}$ mesh cod end liner). Two otter trawl tows each were made over a $50 \mathrm{~m}$ transect while simultaneously collecting crabs from within 2 drop nets deployed nearby. After crabs were separated into 3 size groups, density estimates were compared for the 2 types of gear. In all cases mean density estimates from suction sampling were at least an order of magnitude greater than those determined by trawling: 0.67 vs $0.004 \mathrm{~m}^{-2}$ for crabs $\leq 11 \mathrm{~mm}$ in carapace width; $9.0 \mathrm{vs} 0.34 \mathrm{~m}^{-2}$ for indi- viduals $>11$ to $\leq 25 \mathrm{~mm}$; and 1.7 vs $0.028 \mathrm{~m}^{-2}$ for crabs $>25 \mathrm{~mm}$, respectively. After applying an efficiency factor of $88 \%$ to suction sampling data, it was determined that the trawl was $0.5,0.3$ and $1.4 \%$ effective, respectively, in estimating the abundance of crabs in each size class found in the grassbed.

To test whether drop net sampling in the marsh creek during high tide provided reliable estimates of crab abundance, we conducted preliminary studies on 2 dates by blocking off a $35 \mathrm{~m}$ section of the creek at high tide with a $2 \mathrm{~mm}$ mesh net while at the same time deploying a drop net within the blocked area. We first suctioned and dip-netted for crabs in the drop net and, at low tide, collected and enumerated all crabs from within the blocked netted creek bed. Densities of crabs on the 2 sample dates yielded similar estimates of abundance (block net: 0.16 and $0.45 \mathrm{~m}^{-2}$, vs drop net: 0.11 and $0.39 \mathrm{~m}^{-2}$, respectively) indicating that sampling with drop nets in the creek at high tide yielded estimates of crab densities within the same order of magnitude as those determined by block netting.

\section{RESULTS}

\section{Environmental and standing crop data}

Annual temperatures in the 2 habitats ranged from 0 to $30^{\circ} \mathrm{C}$ (Fig. 3). Continuous water temperature data are presented since these data better represent seasonal variation than do our point data. Our temperature data generally fell within 2 to $3 \mathrm{C}^{\circ}$ of the continuous temperature data. Minimum and maximum temperatures during the $4 \mathrm{yr}$ were similar. Salinity varied seasonally, with maximum salinities (Fig. 3) occurring in late fall and increasing over the $4 \mathrm{yr}$ we sampled, reflecting the decreased total rainfall that occurred from 1984 through 1986. Salinity and water temperature variation between the grassbed and marsh creek was generally $<1 \%$ and 1 to $2 \mathrm{C}^{\circ}$ although differences in temperature of approximately $\pm 5 \mathrm{C}^{\circ}$ did occur during winter and summer. There were no major freshwater inputs into either of the habitats, which were within $500 \mathrm{~m}$ of each other. Vegetation biomass in the grassbed exhibited seasonal variations with maximum aboveground standing crop in early summer and minimum values in the fall (Fig. 3), paralleling patterns described at this site during an earlier investigation (Orth \& Moore 1986).

\section{Faunal data}

Callinectes sapidus exhibited seasonal cycles as well as yearly variations in abundance in the grassbed and 

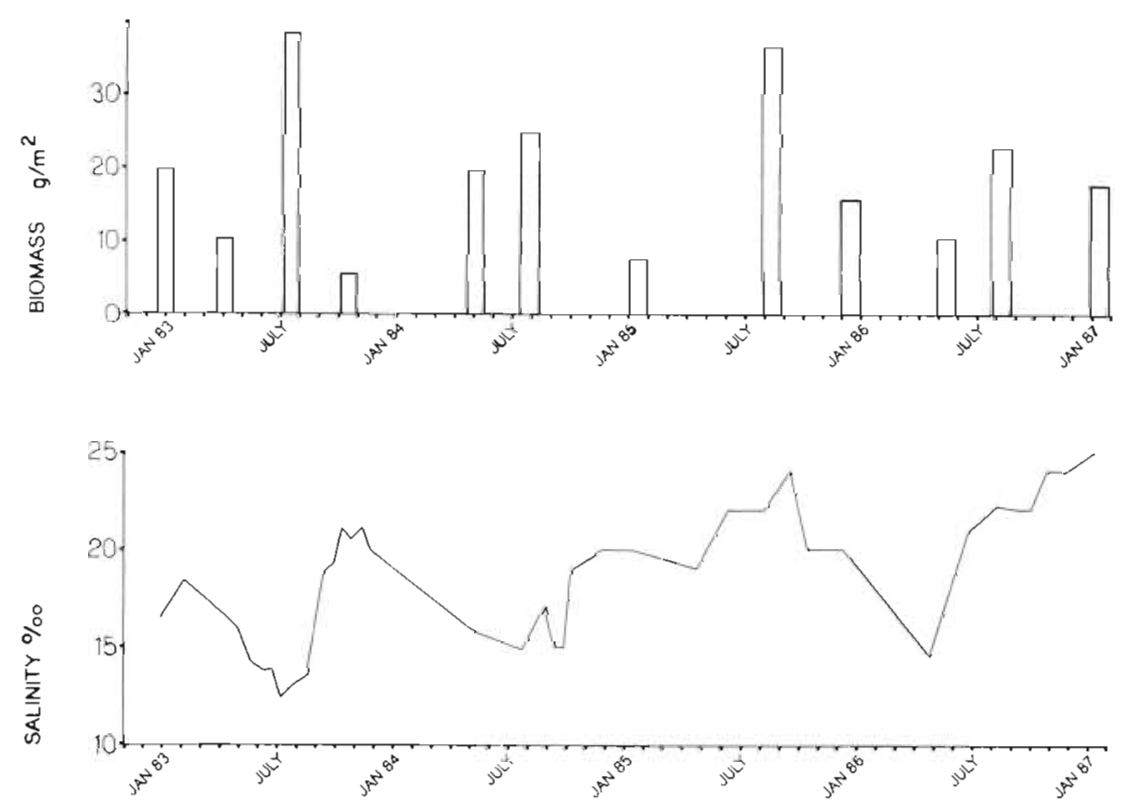

Fig. 3. Variations in aboveground standing crop $\left(\mathrm{g} \mathrm{m}^{-2}\right)$ of vegetation in the seagrass bed at the study site, salinity $(\%)$. and water temperature $\left({ }^{\circ} \mathrm{C}\right)$. Water temperatures were from a constant temperature sensor located $10 \mathrm{~km}$ upriver from our sampling site

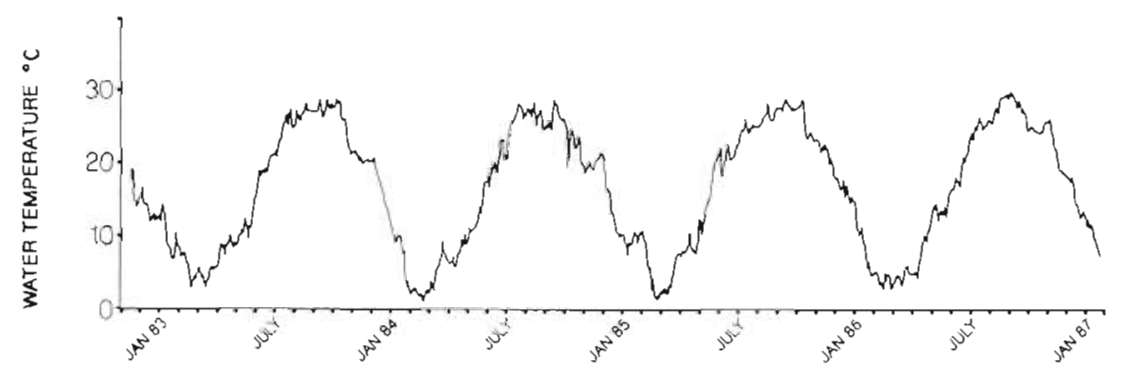

marsh creek (Fig. 4). In the grassbed, mean densities of C. sapidus were always highest in September (up to $90 \mathrm{~m}^{-2}$ ), remained high throughout fall and winter (October to February; up to $24 \mathrm{~m}^{-2}$ ), and gradually decreased through spring (March to June) to the lowest levels (less than 3 crabs $\mathrm{m}^{-2}$ ) by mid-summer (late July to August). In the marsh creek, highest mean densities of C. sapidus also occurred in the fall of each year (up to $8 \mathrm{~m}^{-2}$ ), and lowest densities occurred in the winter (January to March; $0.1 \mathrm{crabs}^{-2}$ ) and summer (June to August; <0.1 $\mathrm{crab} \mathrm{m}^{-2}$ ) (Fig. 4). In 1984, 1985 and 1986, mean densities actually increased through the fall period and were greatest in the last sampling period of that year (usually November and December). Mean densities of $C$. sapidus in the marsh creek were significantly lower ( $\mathrm{p}<0.01$, Mann-Whitney U-test) than in the grassbed for all sampling periods except 15 Aug 1983 and 11 Nov 1985.

Contingency table analysis to examine the effects of year and season on the density of crabs from the grassbed within 4 size groups indicated that the most parsimonious model included the interaction between year and season. Thus, the density of crabs in each size group differed among seasons and this pattern varied annually. For example, a distinct settlement/recruitment pulse occurred in the grassbed during the late summer and fall period (August to November) as evidenced by the crabs in the $<4.25$ and 4.25 to $11.00 \mathrm{~mm}$ size classes, but peaks occurred at slightly different times during different years. Overall, the magnitude of the peaks differed significantly ( $p<0.001$ ) between years and was much lower in 1985 and 1986 compared to the previous 2 yr (Table 1 ; Fig. 4). Although recruitment of Callinectes sapidus in the marsh creek also occurred in late summer and fall, it was not evident until 2 to $4 \mathrm{wk}$ (mid to late September) after it was first observed in the grassbed (Fig. 4) and consisted of 3rd stage and larger juvenile crabs. Mean fall densities of crabs in the first 2 juvenile size classes were noticeably reduced in the marsh creek.

Over $90 \%$ of the Callinectes sapidus collected during most sampling periods (particularly the fall) in the grassbed and marsh creek were $<25 \mathrm{~mm}$ in carapace width. Larger crabs (>25 mm) predominated from June to mid-August (Fig. 4).

An analysis (Kruskal-Wallis 1-way ANOVA) of interannual Callinectes sapidus density patterns in the grassbed (Table 1) indicated significant differences in 
GRASS BED

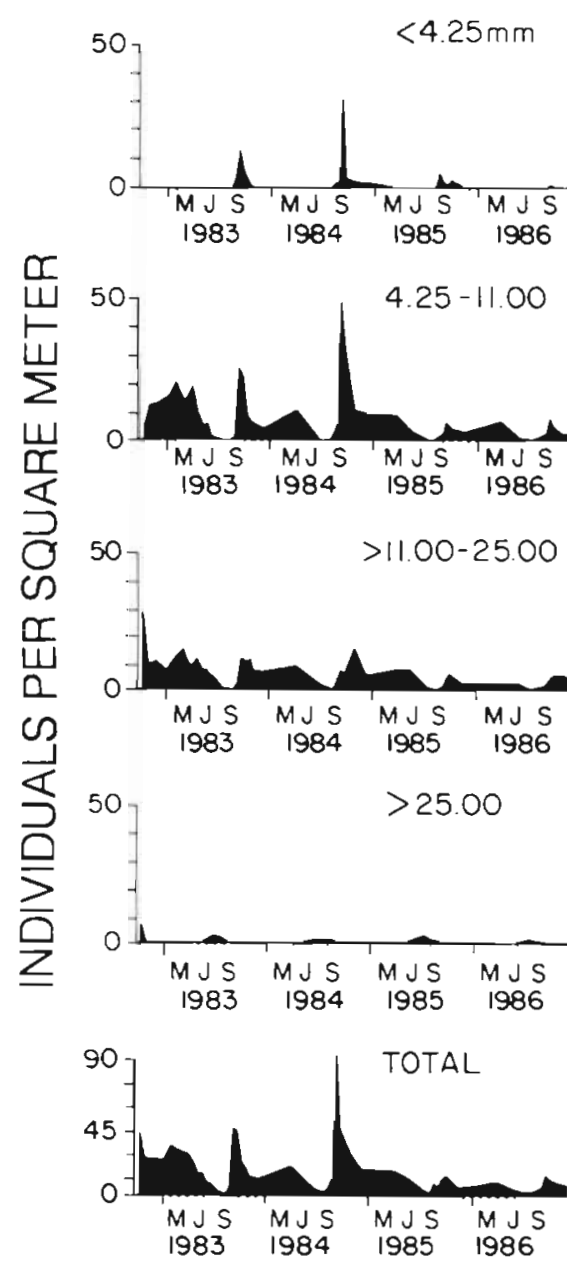

\section{MARSH CREEK}
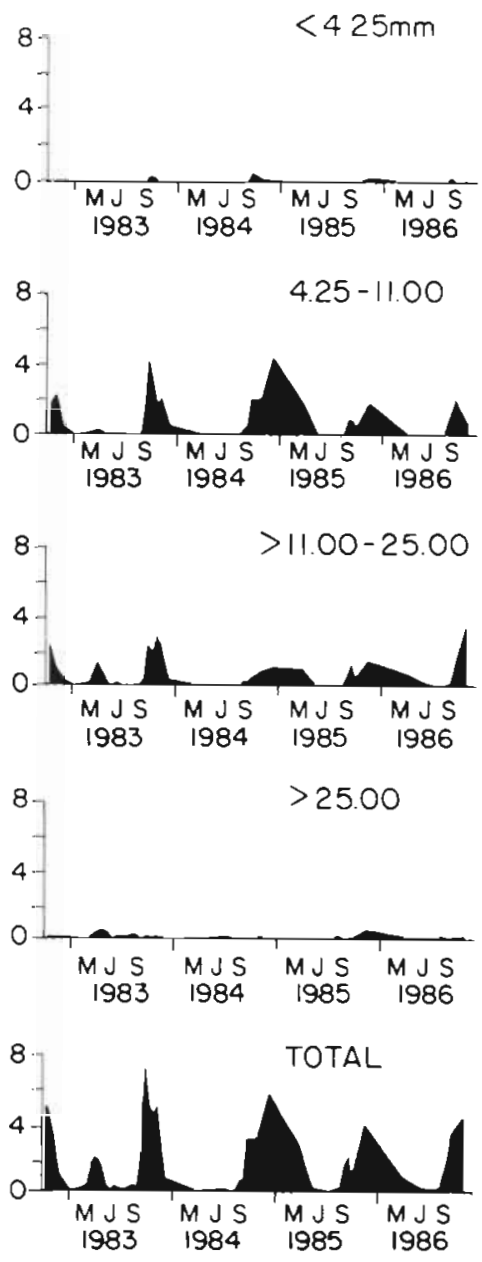

Fig. 4. Callinectes sapidus. Annual and seasonal abundance patterns of 4 size groups of blue crabs residing in a seagrass bed and tidal marsh creek. See text for explanation of size groups used

Table 1. Callinectes sapidus. Kruskal-Wallis 1-way ANOVA analysis of mean ( \pm SD) interannual (1983 to 1986) crab density patterns in the grassbed for crabs in 4 size classes

\begin{tabular}{|lccccc|}
\hline $\begin{array}{l}\text { Size class } \\
\text { (carapace width) }\end{array}$ & 1983 & 1984 & 1985 & 1986 & $\begin{array}{c}\text { Chi-square } \\
\text { significance }\end{array}$ \\
\hline$<4.25 \mathrm{~mm}$ & $3.4( \pm 6.2)$ & $5.6( \pm 11.1)$ & $0.8( \pm 1.2)$ & $0.3( \pm 0.7)$ & $p \leq 0.0001$ \\
$4.25-11.00 \mathrm{~mm}$ & $10.5( \pm 11.4)$ & $15.8( \pm 18.2)$ & $3.4( \pm 3.4)$ & $3.5( \pm 3.1)$ & $p \leq 0.0005$ \\
$>11.00-25.00 \mathrm{~mm}$ & $4.0( \pm 4.6)$ & $4.2( \pm 3.1)$ & $3.0( \pm 2.8)$ & $2.6( \pm 1.9)$ & $p=0.2128$ \\
$>25.00 \mathrm{~mm}$ & $0.6( \pm 0.8)$ & $0.7( \pm 0.8)$ & $0.9( \pm 1.0)$ & $0.6( \pm 0.7)$ & $p=0.1396$ \\
Total & $19.0( \pm 18.7)$ & $27.1( \pm 29.8)$ & $8.1( \pm 5.5)$ & $7.1( \pm 4.4)$ & $p \leq 0.0001$ \\
\hline
\end{tabular}

densities between years for crabs $<4.25 \mathrm{~mm}, 4.25$ to $11 \mathrm{~mm}$ and total crab abundance whereas such differences were not evident for crabs in the larger 2 size classes ( 11 to $25 \mathrm{~mm}$ and $>25 \mathrm{~mm}$ ). Overall, mean crab densities were depressed during 1985 (8.1 $\left.\mathrm{m}^{-2}\right)$ and $1986\left(7.1 \mathrm{~m}^{-2}\right)$ relative to 1983 and 1984 when higher densities (19.0 $\mathrm{m}^{-2}$ and $27.1 \mathrm{~m}^{-2}$, respectively) were found.

For the combined data set (all months and all years), males made up a significantly larger percentage of the population ( $\mathrm{p} \leq 0.001$, chi-squared test) in the marsh creek $(50.4 \%$ males) than in the grassbed $143.9 \%$ 
males). Contingency table analysis of sex ratios indicated that the most parsimonious model included 2way interactions of sex by habitat and sex by month but the 3-way interaction of sex by habitat by month did not increase model fit significantly. Thus, the observed differences in sex ratios between the marsh creek and grassbed were consistent throughout each year.

\section{DISCUSSION}

\section{Sampling methodology comparisons}

Abundance and size distribution data in our study contrast markedly with results of several trawl studies (Miller et al. 1975, Heck \& Orth 1980, Weinstein \& Brooks 1983, Heck \& Thoman 1984) done in similar Chesapeake Bay habitats (Table 2). Data from these studies were compared by grouping crabs into 2 size categories: those $\leq 25 \mathrm{~mm}$ reflecting individuals which would be less efficiently captured by otter trawling and those $>25 \mathrm{~mm}$ which would be more likely collected by otter trawling. We recognize the limitations inherent in making such comparisons because of the differences in mesh size (trawl: $6.3 \mathrm{~mm}$ vs our sampling frame: 1.3 $\mathrm{mm}$ ), and capture efficiencies (trawl: 1 to $20 \%$, this study and Homer et al. 1980, vs suction sampling: $88 \%$, this study) of the sampling gear used and differences in crab abundance among sites and years studied. With these limitations in mind, total density of Callinectes sapidus are 1 to 2 orders of magnitude less in the trawl studies and crabs larger than $25 \mathrm{~mm}$ are underestimated by at least an order of magnitude. Further support for the effectiveness of suction sampling versus otter trawling can be gleaned by comparing published crab densities obtained in the same grassbed using the 2 sampling techniques. Initial sampling by Penry (1982) overlapped the last sampling date of Heck \& Thoman (1984). Crab densities reported by Penry are 2 orders of magnitude higher. Furthermore, our results verify that trawls underestimate densities of crabs by 1 to 2 orders of magnitude when compared to densities obtained by suction sampling Preliminary estimates of trawl efficiency in vegetated habitats from our work range from $0.4 \%$ for crabs $<25 \mathrm{~mm}$ wide to $1.4 \%$ for crabs $>25 \mathrm{~mm}$ wide.

The greatest drawback of trawls is their underestimate of not only the total abundance of the crabs but, more importantly, the abundance of the smallest sized crabs which form the largest proportion of the population present in Chesapeake Bay grassbeds during most of the year. Similar conclusions about the effectiveness of suction sampling were reached by Zimmerman \& Minello (1984) and Zimmerman et al. (1984) when sampling penaeid shrimp and blue crabs in a Texas salt marsh.

\section{Spatial and temporal abundance patterns}

The seasonal cycles of Callinectes sapidus abundance in both the grassbed and marsh creek indicated that the new year class entered these habitats during late summer to early fall. In general, first and second stage crabs were present from August through December, especially in the grassbed, with peak abundances in September. We believe that megalopal settlement contributed significantly to the abundance of C. sapidus juveniles. C. sapidus megalopae were collected using neuston nets and passive collectors in the grassbed, marsh creek and other unvegetated sites during September of 1984, 1985, and 1986 (unpubl. data). The large numbers of megalopae collected in 1984 were reflected in the considerably higher densities of $C$. sapidus juveniles found in the grassbed in 1984 and contrasted with much lower numbers of each collected in 1985 and 1986. C. sapidus megalopae have previously been reported from August through November in Chesapeake Bay plankton samples (Sandifer 1975, McConaugha et al. 1983, D. F. Johnson 1985, Virginia Institute of Marine Science unpubl. data reports). Thus megalopae appear to be a regular and abundant component of the meroplankton during the late summer and fall. Our data indicate that interannual variations in the settlement densities of C. sapidus, particularly in Chesapeake Bay grass beds, may be related to the supply of megalopae during late summer and fall. Dispersal into shallow habitats by early stage crabs may also be important (Meredith 1982).

Small-scale variations in the supply of megalopae to the marsh creek and grassbed could, in part, account for the 10-fold increased abundance of early juvenile Callinectes sapidus in the grassbed when compared to the marsh creek during late summer and fall. However, based on the abundance of megalopae in passive collectors and preliminary neuston samples from the 2 habitats (unpubl. data), we do not feel that supply rates are substantially different. Other factors including hydrodynamic effects of seagrasses, active selection by megalopae for submerged vegetation, increased food availability in grassbeds, and reduced predation in highly structured habitats could potentially promote greater densities of $C$. sapidus (especially those $<11 \mathrm{~mm}$ ) in seagrass beds.

Hydrodynamic effects by seagrasses may enhance the passive settlement of megalopae into the grassbed. It has been demonstrated that seagrasses modify current regimes resulting in the deposition of passive 
Table 2. Callinectes sapidus. Comparison of densities collected seasonally from vegetated and unvegetated habitats using different collecting gear Trawl data were converted to $\mathrm{m}^{2}$ density by dividing total number of crabs collected by distance trawled (ca $120 \mathrm{~m}$ ) $\times$ trawl opening size $(4.9 \mathrm{~m}) \times$ number of trawls $(6)$. Trawl speed and distance trawled were similar for Weinstein \& Brooks, Heck \& Orth, and Heck \& Thoman. Heck \& Orth, Heck \& Thoman and Penry sampled at the same site which was approximately $5 \mathrm{~km}$ from our site. Data from our study are representative points during the sampling period indicative of the maximum seasonal variation in densities we observed

\begin{tabular}{|c|c|c|c|c|c|c|}
\hline Author & Habitat/area & $\begin{array}{l}\text { Sampling } \\
\text { method }\end{array}$ & $\begin{array}{l}\text { Total density } \\
\qquad\left(m^{-2}\right)\end{array}$ & \multicolumn{2}{|c|}{$\begin{array}{l}\text { Density }\left(\mathrm{m}^{-2}\right) \\
\text { by size class }\end{array}$} & $\begin{array}{l}\text { Sampling } \\
\text { date }\end{array}$ \\
\hline & & & & $<60 \mathrm{~mm}$ & $>60 \mathrm{~mm}$ & \\
\hline \multirow[t]{4}{*}{ Miller et al. 1975} & Sand/Chesapeake Bay & Trawl $(7.6 \mathrm{~m}, 6.3 \mathrm{~mm}$ & 0.015 & 0.003 & 0.012 & Aug 1971 \\
\hline & & mesh liner) & 0.007 & 0.003 & 0.004 & Dec 1971 \\
\hline & & Dredge $(12.8 \mathrm{~mm}$ mesh & 0.007 & 0.001 & 0.006 & Jun 1972 \\
\hline & & liner) & 0.006 & 0.001 & 0.005 & Aug 1972 \\
\hline \multirow{6}{*}{ Heck \& Orth 1980} & & & & $<25 \mathrm{~mm}$ & $>25 \mathrm{~mm}$ & \\
\hline & Zostera marinal & Trawl $(4.9 \mathrm{~m}, 6.3 \mathrm{~mm}$ & 0.124 & 0.081 & 0.043 & Sep 1976 \\
\hline & Chesapeake Bay & mesh liner) & 0.034 & 0.028 & 0.006 & Oct 1976 \\
\hline & & & 0 & 0 & 0 & Dec 1976 \\
\hline & & & 0.059 & 0.047 & 0.012 & Apr 1977 \\
\hline & & & 0.016 & 0 & 0.016 & Jul 1977 \\
\hline \multirow{7}{*}{$\begin{array}{l}\text { Weinstein \& Brooks } \\
1983\end{array}$} & Zostera marinal & Trawl $(4.9 \mathrm{~m}, 6.3 \mathrm{~mm}$ & 0.051 & \multirow{3}{*}{\multicolumn{2}{|c|}{$\begin{array}{c}\text { No size class data } \\
\text { available }\end{array}$}} & Apr 1982 \\
\hline & Chesapeake Bay & mesh liner) & 0.036 & & & Aug 1982 \\
\hline & & & $\begin{array}{l}0.038 \\
0.054\end{array}$ & & & $\begin{array}{l}\text { Sep } 1982 \\
\text { Oct } 1982\end{array}$ \\
\hline & Spartina alterniflora & Trawl $(4.9 \mathrm{~m}, 6.3 \mathrm{~mm}$ & 0.110 & & & Apr 1982 \\
\hline & Creek/Chesapeake Bay & mesh liner) & 0.027 & & & Aug 1982 \\
\hline & & & 0.034 & & & Sep 1982 \\
\hline & & & 0.016 & & & Oct 1982 \\
\hline \multirow[t]{7}{*}{ Penry 1982} & Zostera marina/ & Drop net, suction & 20.2 & 19.3 & 0.9 & Oct 1980 \\
\hline & Chesapeake Bay & dredge (collection bag, & 12.4 & 12.2 & 0.2 & $\operatorname{Jan} 1981$ \\
\hline & & $1.0 \times 1.5 \mathrm{~mm}$ mesh) & 5.3 & 4.8 & 0.5 & Apr 1981 \\
\hline & & & 3.5 & 1.7 & 1.8 & Jun 1981 \\
\hline & Sand/Chesapeake Bay & Drop net, suction & 0.6 & 0.1 & 0.5 & Oct 1980 \\
\hline & & dredge (collection bag, & 0.2 & 0.2 & 0 & $\operatorname{Jan} 1981$ \\
\hline & & $1.0 \times 1.5 \mathrm{~mm}$ mesh) & 0.8 & 0.6 & 0.2 & Apr 1981 \\
\hline \multirow{8}{*}{$\begin{array}{l}\text { Heck \& Thoman } \\
1984\end{array}$} & Zostera marinar & Trawl $(4.9 \mathrm{~m}, 6.3 \mathrm{~mm}$ & 0.007 & 0.003 & 0.004 & Oct 1978 \\
\hline & Chesapeake Bay & mesh liner) & 0 & 0 & 0 & Mar 1979 \\
\hline & & & 0.056 & 0.043 & 0.013 & Apr 1979 \\
\hline & & & 0.146 & 0.014 & 0.132 & Jun 1979 \\
\hline & & & 0.072 & 0 & 0.072 & Aug 1979 \\
\hline & & & 0.031 & 0.001 & 0.030 & Oct 1979 \\
\hline & & & 0.019 & 0.002 & 0.017 & May 1980 \\
\hline & & & 0.018 & 0.002 & 0.016 & Oct 1980 \\
\hline \multirow[t]{10}{*}{ This study } & Zostera-Ruppial & Drop net, suction & 40.7 & 33.8 & 6.9 & Oct 1982 \\
\hline & Chesapeake Bay & dredge (collection bag & 32.3 & 32.1 & 0.2 & Feb 1983 \\
\hline & & $1.2 \mathrm{~mm}$ mesh) & 0.8 & 0.2 & 0.6 & Aug 1983 \\
\hline & & & 89.9 & 89.2 & 0.7 & Sep 1984 \\
\hline & & & 13.1 & 12.5 & 0.6 & Sep 1985 \\
\hline & Marsh creek & Same as above & 4.8 & 4.7 & 0.1 & Oct 1982 \\
\hline & & & 0.1 & 0.1 & 0 & Feb 1983 \\
\hline & & & 0.4 & 0.1 & 0.3 & Aug 1983 \\
\hline & & & 0.6 & 0.6 & 0 & Sep 1984 \\
\hline & & & 0.7 & 0.6 & 0.1 & Sep 1985 \\
\hline
\end{tabular}

sediment particles (Fonseca et al, 1982) but little is known about the response by actively swimming larvae to current flow modifications. Eckman (1987) found that hydrodynamic effects in a Zostera marina bed exerted a strong positive influence on recruitment of one of 2 sessile, suspension-feeding bivalve species, implying a possible mechanism for enhancing Iarval settlement.

Alternatively, the larvae of some species of marine benthic organisms are known to actively select certain substrates (Scheltema 1974, Lewis 1977). Megalopae and juvenile Callinectes sapidus may use chemical or 
tactile cues to select grassbeds over marsh habitats. Our current research indicates that under static laboratory and field conditions, C. sapidus megalopae are capable of actively selecting Zostera marina over other substrates offered (unpubl.).

Furthermore, seagrass beds support a more diverse and dense macro- and meiofaunal assemblage than unvegetated habitats (Bell et al. 1984, Orth et al. 1984a), many species of which are found in the diet of Callinectes sapidus (Laughlin 1982). This greater abundance of food could potentially support higher densities of $C$. sapidus.

Finally, habitat structure is an important mediator of predation in marine, estuarine, and freshwater habitats (Vince et al. 1976, Crowder \& Cooper 1982, Minello \& Zimmerman 1983, Orth et al. 1984a). As percent cover increases to a critical density, predation risk declines (Coen et al. 1981, Heck \& Thoman 1981, Wilson et al. 1987). Although both habitats are vegetated, the degree of refuge afforded by marsh vegetation varies tidally. Callinectes sapidus juveniles may therefore be concentrated in the unvegetated creek bottom as the tide ebbs and could be more susceptible to predation than those inhabiting continuously submerged seagrass beds. The relative influence of each of the above factors in determining the abundance of small crabs in various habitats is unknown at present but some speculation may be justified.

Abundance and size frequency data from the marsh creek and grassbed suggest that predation may act in concert with active substrate selection (unpubl.) to explain the observed patterns of Callinectes sapidus population structure. The virtual absence of stage 1 and 2 juvenile crabs in the marsh creek and the presence of larger recruits ( $>3 \mathrm{rd}$ stage juveniles), 2 to $4 \mathrm{wk}$ after settlement was first observed in the grassbed, may result from predation on initial settlers and larger individuals moving to the marsh creek from the grassbed after selective settlement. As crabs grow larger, they may begin to attain some degree of refuge in size from marsh creek predators, notably mummichog Fundulus heteroclitus (Kneib 1984, 1986) and other fish predators (e.g. Anchoa mitchilli and Menidia menidia [Weinstein \& Brooks 1983]). The increased abundance of $C$. sapidus juveniles observed in the marsh creek during late fall and early winter may reflect a continuous influx of juveniles from other areas and the coincident exodus of predators from the creeks due to falling water temperatures.

In September of 1983 and 1984, when high densities of small Callinectes sapidus occurred in the grassbed, a precipitous decline in abundance of the 2 smallest size classes occurred over a 2 to $4 \mathrm{wk}$ period following peak settlement. Abundance may initially be regulated by density-dependent factors, intense predation on the very small individuals, rapid growth into larger size classes, or rapid migration out of the grassbed to other unknown habitats.

Callinectes sapidus $>25 \mathrm{~mm}$ make up the smallest percentage of the population in the shallow water habitats we investigated. Furthermore, interannual densities of crabs $>25 \mathrm{~mm}$ and 11 to $25 \mathrm{~mm}$ in the grassbed were not significantly different despite the significantly higher densities of individuals $<11 \mathrm{~mm}$ during 1983 and 1984 than occurred the following 2 yr. Had initial settlers and recruits remained in the grassbed and had mortality remained proportional during years of high and low settlement, one would have expected to see the high settlement densities reflected in the increased abundance of larger crabs through time as they grew. Thus, mortality (predation or cannibalism) may be density dependent or $C$. sapidus between 11 and $25 \mathrm{~mm}$ may undergo an ontogenetic shift in habitat use from grassbeds to other unknown habitats. This shift may be related to crabs attaining a refuge in size from predation (Orth et al. 1984a), spatial limitations, and/or energetic considerations. An analogous situation occurs with the spiny lobster Panulirus argus. Young $P$. argus $(6$ to $17 \mathrm{~mm}$ carapace length) are more abundant in algal clumps, where refuge and food are present in one unit, while larger individuals are found in dens removed from feeding sites (Marx \& Herrnkind 1985). Additionally, densities of the brown shrimp Penaeus aztecus are significantly higher in Texas salt marshes when compared to unvegetated bottoms and $95 \%$ of the individuals collected in the marsh are less than $20 \mathrm{~mm}$ in carapace length (Zimmerman et al. 1984) suggesting a similar shift in habitat use for this species.

Winter samples collected in 1983 (January and February) indicated the presence of large numbers of Callinectes sapidus $<25 \mathrm{~mm}$ in the grassbed but not in the marsh creek. These individuals were buried in the substrate and remained inactive because of reduced water temperatures $\left(<10^{\circ} \mathrm{C}\right.$ i pers. obs.). Although we did not sample these areas in subsequent winters, we believe that this is a regularly occurring pattern; 2 previous studies in nearby Chesapeake Bay vegetated areas reported similar patterns of winter C. sapidus abundance (Diaz \& Fredette 1982, Penry 1982). Thus, conclusions from trawl studies that virtually no $C$. sapidus overwintered in Chesapeake Bay grassbeds (Heck \& Orth 1980, Heck \& Thoman 1984) appear to be false and may be due to the inability of the trawl to sample buried crabs. The winter use of vegetated shoal habitat by juvenile $C$. sapidus contrasts with that of adults which move offshore and burrow in deeper, muddy-sand bottoms of main-stem Chesapeake Bay basins (van Engel 1958, Schaffner \& Diaz in press).

The higher ratio of males to females in the marsh 
creek (49 to $58 \%$ males) than in the grassbed $(\sim 44 \%$ males) occurred annually. Reasons for such habitatrelated differences in sex ratios remain obscure but may reflect sexual differences in physiological tolerances to temperature and salinity, sex-related differential predation or habitat partitioning by sex. Although no striking differences in these physical parameters were apparent in our data, different sexes of Callinectes sapidus may respond to subtle environmental cues not detected in our study. Hines et al. (1987) found $C$. sapidus in the Rhode River (a subestuary of the Chesapeake Bay) to partition creek habitats by sex, size, and molt stage. These patterns may be repeated on small spatial scales such as in our study.

Conclusions from our study should be extrapolated to similar habitats with caution. We have provided further support to the often cited nursery function of these shallow water habitats (Orth et al. 1984b). Our results suggest that Callinectes sapidus are responding differently in the grassbed than in the adjacent marsh creek to biotic and/or abiotic factors. The precise mechanisms that allow for greater densities in vegetated habitats have not been completely examined nor understood, but most frequently have been related to a refuge from predation (Orth et al. 1984b). Aspects of cannibalism, substrate selection by settling $C$. sapidus megalopae post-settlement mortality, and migratory patterns of early juvenile crabs within and between habitats require further investigation.

The functional relationships and nursery value of various habitats in other estuaries and bays throughout the distributional range of Callinectes sapidus also remain poorly understood. Latitudinal differences in the biotic and abiotic characteristics of estuaries may cause them to function differently with respect to populations of $C$. sapidus. Only by using comparable and accurate sampling techniques and similar experimental approaches within like habitats can the relative value of these habitats in the population dynamics of C. sapidus be assessed on a geographical scale.

Acknowledgements. We are indebted to many people who have contributed to all phases of this project from conception, through many months of tedious field work and sample sorting to reviewing the completed manuscript. For field and laboratory work, we thank Lee Aldrich, Betty Bieri, Gem Blair, Shannon Burcham, Cathy Clemons, Cathy Dryden, Michelle Feeley, Curtis Harper, Keith Havens, Janet Hearth, Jan Hodges, Hilary Neckles, Chris Peery, Matt Pivarnik, Tim Smithwick, Sandra Yarrington, Robert Young and, in particular, Judy Capelli who has persisted for the duration of this project and kept all the samples in order. Special thanks go to Cliff Ryer who has played an integral role in the data analysis and to Hilary Neckles for her help with contingency table analysis. Cliff Ryer was also a major participant in all the field work. We thank Rom Lipcius, Mark Luckenbach, W. van Engel, Mike Oesterling and 2 anonymous reviewers for their very helpful comments on the manuscript. This work is a result of research sponsored in part by the Virginia Institute of Marine Science, a private grant from Allied Chemical Corp. and by the National Sea Grant College Program of the National Oceanic and Atmospheric Administration, U.S. Department of Commerce, under Grant No. NA86AA-DSG042 to the Virginia Graduate Marine Science Consortium and the Virginia Sea Grant College Program. The U. S. Government is authorized to produce and distribute reprints for governmental purposes notwithstanding any copyright notation that may appear hereon.

\section{LITERATURE CITED}

Bell, S. S., Walters, K., Kern, J. C. (1984). Melofauna from seagrass habitats: a review and prospectus for future research. Estuaries 7: 331-338

Brookins, K. G., Epifanio, C. E. (1985). Abundance of brachyuran larvae in a small coastal inlet over six consecutive tidal cycles. Estauries 8: 60-67

Coen, L. D., Heck, K. L., Jr., Abele, L. G. (1981). Experiments on competition and predation among shrimps of seagrass meadows. Ecology 62: 1484-1493

Connell, J. H. (1985). The consequences of variation in initial settlement vs post-settlement mortality in rocky intertidal communities. J. exp. mar. Biol. Ecol. 93: 11-45

Crowder, L. B., Cooper, W. E. (1982). Habitat structural complexity and the interaction between bluegills and their prey. Ecology 63: 1802-1813

Diaz, R. J., Fredette, T (1982). Secondary production of some dominant macroinvertebrate species inhabiting a bed of submerged vegetation in the lower Chesapeake Bay. In: Orth, R. J., van Montfrans, J. (ed.) Interactions of resident consumers in a temperate estuarine seagrass community. VIMS-SRAMSOE No. 267, Vaucluse Shores, Virginia, p. 95-123

Dittel, A. I., Epifanio, C. E. (1982). Seasonal abundance and vertical distribution of crab larvae in Delaware Bay. Estuaries 5: 197-202

Eckman, J. E. (1987). The role of hydrodynamics in recruitment, growth, and survival of Argopecten irradians (L.) and Anomia simplex (D'Orbigny) within eelgrass meadows. J. exp. mar Biol. Ecol. 106: 165-191

Epifanio, C. E., Dittel, A. I. (1982). Comparison of dispersal of crab larvae in Delaware Bay, USA, and the Gulf of Nicoya, Central America. In: Kennedy, V S. (ed.) Estuarine comparisons. Academic Press, New York, p. 477-487

Epifanio, C. E., Valenti, C. C., Pembroke, A. E. (1984). Dispersal and recruitment of blue crab larvae in Delaware Bay, U.S.A. Estuar coast. Shelf Sci. 18: 1-1.2

Fienberg, S. E. (1980). Analysis of cross-classified categorical data. MIT Press, Cambridge, Massachusetts

Fonseca, M. S., Zieman, J. C., Thayer, G. W., Fisher, J. S. (1982). Influence of the seagrass, Zostera marina, on current flow. Estuar. coast. Shelf Sci. 15: 351-364

Heck, K. L., Jr., Orth, R. J. (1980). Structural components of eelgrass (Zostera marina) meadows in the lower Chesapeake Bay - decapod crustacea. Estuary 3: 289-295

Heck, K. L., Jr., Thoman, T. (1981). Experiments on predatorprey interactions in vegetated aquatic habitats. J. exp. mar Biol. Ecol. 53: 125-134

Heck, K. L., Jr., Thoman, T. A. (1984). The nursery role of seagrass meadows in the upper and lower reaches of the Chesapeake Bay. Estuaries 7: 70-92

Hines, A. H., Lipcius, R. N., Haddon, A. H. (1987). Population 
dynamics and habitat partitioning by size, sex, and molt. stage of blue crabs Callinectes sapidus in a subestuary of central Chesapeake Bay. Mar Ecol. Prog. Ser. 36: 55-64

Homer, M., Mihursky, J. A., Jones, P. (1980). Quantitative approaches towards characterizing estuarine fish populations and communities. Proc. Am. Fish. Soc., Potomac Chapter, 4th Annual Meeting, p. 39-99

Johnson, D. F. (1982). A comparison of recruitment strategies among brachyuran crustacean megalopae of the York River, lower Chesapeake Bay and adjacent shelf waters. $\mathrm{Ph}$. D. dissertation, Old Dominion University. Norfolk, Virginia

Johnson, D. F. (1985). The distribution of brachyuran crustacean megalopae in the waters of the York River, lower Chesapeake Bay and adjacent shelf: implications for recruitment. Estuar, coast. Shelf Sci. 20:693-705

Johnson, D. R. (1985). Wind-forced dispersion of blue crab larvae in the Middle Atlantic Bight. Cont. Shelf Res. 6: $733-745$

Johnson, D. R., Hester, B. S., McConaugha, J. R. (1984). Studies of a wind mechanism influencing the recruitment of blue crabs in the Middle Atlantic Bight. Cont. Shelf Res. 3: $425-437$

Keough, M. J., Downes, B. J. (1982). Recruitment of marine invertebrates: the role of active larval choices and early mortality. Oecologia (Berl.) 54: 348-352

Kneib, R. T. (1984). Patterns in the utilization of the intertidal salt marsh by larvae and juveniles of Fundulus heteroclitus (Linnaeus) and Fundulus luciae (Baird). J. exp. mar. Biol. Ecol. 83: 41-51

Kneib, R. T. (1986). The role of Fundulus heteroclitus in salt marsh trophic dynamics. Am. Zool. 26: 259-269

Laughlin, R. A. (1982). Feeding habits of the blue crab, Callinectes sapidus Rathbun, in the Apalachicola estuary, Florida. Bull. mar. Sci. 32: 807-822

Lewis, C. A. (1977). A review of substratum selection in freeliving and symbiotic cirripeds. In: Chia, F. S., Rice, M. (ed.) Settlement and metamorphosis of marine invertebrate larvae. Elsevier, Amsterdam, p. 207-217

Marx, J. M., Herrnkind, W. F. (1985). Macroalgae (Rhodophyta: Laurencia spp.) as habitat for young juvenile spiny lobsters, Panulirus argus. Bull. mar. Sci. 36: 423-431

McConaugha, J. R., Johnson, D. F., Provensano, A. J., Maris, R. C. (1983). Seasonal distribution of larvae of Callinectes sapidus (Crustacea: Decapoda) in the waters adjacent to Chesapeake Bay. J. Crust. Biol. 3: 582-591

Meredith, W. H. (1982). The dynamics of zooplankton and micronekton community structure across a salt marshestuarine waters interface of lower Delaware Bay. Ph. D. dissertation, University of Delaware, Newark

Miller, R. E., Sulkin, S. D., Lippson, R. L. (1975). Composition and seasonal abundance of the blue crab, Callinectes sapidus Rathbun, in the Chesapeake and Delaware Canal and adjacent waters. Chesapeake Sci. 16: 27-31

Millikin, M. R., Williams, A. B. (1984). Synopsis of biological data on the blue crab, Callinectes sapidus Rathbun. NOAA Tech. Rep. NMFS 1, FAO Fisheries Synopsis No. 138, p. $1-39$

Minello, T. J., Zimmerman, R. J. (1983). Fish predation on juvenile brown shrimp, Penaeus aztecus Ives: the effect of simulated Spartina structure on predation rates. J. exp. mar. Biol. Ecol. 72: 211-231

Orth, R. J., Heck, K. L., Jr., van Montfrans, J. (1984a). Faunal communities in seagrass beds: a review of the influence of plant structure and prey characteristics on predator-prey relationships. Estuaries 7: 339-350

Orth, R. J., Heck, K. L., Jr., Weinstein, M. P. (1984b). Faunal relationships in seagrass and marsh ecosystems. Estuaries 4: $276-470$

Orth, R. J., Moore, K. A. (1986). Seasonal and year-to-year variations in the growth of Zostera marina L. (eelgrass) in lower Chesapeake Bay. Aquat. Bot. 24: 335-341

Penry, D. L. (1982). Utilization of a Zostera marina and Ruppia maritima habitat by four decapods with emphasis on Callinectes sapidus. M. S. thesis, College of William and Mary, Williamsburg, Virginia

Provenzano, A. J., Jr., McConaugha, J. R., Philips, K. B., Johnson, D. F., Clark, J. (1983). Vertical distribution of first stage larvae of the blue crab, Callinectes sapidus, at the mouth of the Chesapeake Bay. Estuar. coast. Shelf Sci. 16: 489-499

Sandifer, P. A. (1975). The role of pelagic larvae in recruitment to populations of adult decapod crustaceans in the York River estuary and adjacent lower Chesapeake Bay, Virginia. Estuar. coast. mar. Sci. 3: 269-279

Schaffner, L. C., Diaz, R. J. (in press). Distribution and abundance of overwintering blue crabs, Callinectes sapidus, in the lower Chesapeake Bay. Estuaries

Scheltema, R. S. (1974). Biological interactions determining larval settlement of marine invertebrates. Thalassia jugosl. 10: $263-296$

Sokal, R. R., Rohlf, F. J. (1981). Biometry. W. H. Freeman, San Francisco

Sulkin, S. D. (1984). Behavioral basis of depth regulation in the larvae of brachyuran crabs. Mar. Ecol. Prog. Ser. 15: $181-205$

Sulkin, S. D., Epifanio, C. E., Provenzano, A. (1982). Proceedings of a workshop in recruitment of the blue crab in middle-Atlantic Bight estuaries. Tech. Rep., MD Sea Grant Program, College Park, Maryland, Publ. No. UM-SG-TS$82-04$, p. $1-36$

Sulkin, S. D., Van Heukelem, W. (1982). Larval recruitment in the crab Callinectes sapidus Rathbun: an amendment to the concept of larval retention in estuaries. In: Kennedy, V. (ed.) Estuarine comparisons. Academic Press, New York, p. $459-475$

Sulkin, S. D., Van Heukelem, W., Kelly, P., Van Heukelem, L. (1980). The behavioral basis of larval recruitment in the crab Callinectes sapidus Rathbun: a laboratory investigation of ontogenetic changes in geotaxis and barokinesis. Biol. Bull. mar biol. Lab., Woods Hole 159: 402-417

Van Den Avyle, M. J., Fowler, D. L. (1984). Species profiles: life histories and environmental requirements of cudstal fishes and invertebrates (South Atlantic): blue crab. U.S. Fish Wildl Serv. FWS/OBS-82/11.19. U. S. Army Corps of Engineers, TR EL-82-4, p. 1-16

Van Engel, W. (1958). The blue crab fishery in Chesapeake Bay. Com. Fish. Rev. 20: 6-17

Vince, S., Valiela, I., Backus, N., Teal, J. M. (1976). Predation by the salt marsh killifish Fundulus heteroclitus (L.) in relation to prey size and habitat structure: consequences for prey distribution and abundance. J. exp. mar. Biol. Ecol. 23: 255-266

Weinstein, M. P., Brooks, H. A. (1983). Comparative ecology of nekton residing in a tidal creek and adjacent seagrass meadow: community composition and structure. Mar. Ecol. Prog. Ser. 12: 15-27

Wethey, D. S. (1985). Local and regional variation in settlement and survival in the intertidal barnacle Semibalanus balanoides: patterns and consequences. In: Moore, P. G., Seed, R. (ed.) The ecology of rocky coasts. Hadder and Stoughton, Sevenoaks, England, p. 194-202

Wilson, K. A., Heck, K. L., Jr., A.ble, K. W. (1987). Juvenile blue crab, Callinectes sapidus, survival: an evaluation of 
eelgrass, Zostera marina, as refuge. Fish. Bull. U. S. 85 : $53-58$

Zimmerman, R. J., Minello, T J. (1984). Densities of Penaeus aztecus, Penaeus setiferus, and other natant macrofauna in a Texas salt marsh. Estuary 7: 421-433
Zimmerman, R. J., Minello, T J., Zamora, G., Jr. (1984) Selection of vegetated habitat by brown shrimp, Penaeus aztecus, in a Galveston Bay salt marsh. Fish. Bull. U. S. 82 $325-336$

This article was presented by Dr G. W Thayer; it was accepted for printing on October 1, 1987 